\title{
The Effectiveness of Fashion Influencers in Influencing the Purchase Interest of Millennial Generation Consumers in Indonesia
}

\author{
Zahra Bhima Absharina ${ }^{1} \square$ Anita Dwi Yuriani ${ }^{2}$ and Evelyn Hendriana ${ }^{3}$ \\ ${ }^{123}$ Management Department, BINUS Business School Master Program, Bina Nusantara University, Jakarta, Indonesia \\ $\square$ Corresponding Author: Zahra Bhima Absharina, E-mail: zahra.absharina@binus.ac.id
}

ARTICLE INFORMATION ABSTRACT

Received: 01 September 2021

Accepted: 28 October 2021

Published: 03 November 2021

DOI: 10.32996/jbms.2021.3.2.16

\section{KEYWORDS}

Attitude, Brand-influencer congruence, Millennial consumer, Purchase intention, Self-influencer congruence, Social media influencer
The widespread acceptance of social media encourages marketers to use social media for brand promotion. Promotions through social media generally target millennials and $\mathrm{Z}$ generations who are more technology literate than their predecessors are. One of the social media promotion techniques is influencer marketing. Most research on the effectiveness of social media influencers only emphasizes the characteristics of influencers, while the match between the influencer's image and the brand being promoted and the ideal self-image of followers also shape consumer attitudes and purchase intentions. However, there are not many studies that integrate these characteristics to explain their influence on brand attitudes and purchase intentions. This study aims to analyze the effect of social media influencer characteristics, influencer-brand congruence, and self-influencer congruence on purchase intention through attitudes towards brands in the millennial generation. Data were collected from 250 respondents selected by purposive sampling technique. Data were analyzed using PLS-SEM. Of the three characteristics of personal influencers, only expertise and attractiveness are proven to influence consumer attitudes towards brands. Selfinfluencer congruence has a positive influence on brand attitudes. Meanwhile, the influence of influencer-brand congruence on consumer attitudes towards the advertised brand is not significant. This study also found that attitude toward a brand has a positive effect on consumer purchase intention.

\section{Introduction}

The development of digital technology affects consumer behavior, one of which is in terms of interacting and seeking information which is currently facilitated by social media. According to We Are Social (2020), global social media users grew by more than $10 \%$ over the past year, to 3.96 billion in early July 2020. This trend encourages businesses to use social media to inform their brands, so they can generate interest in the intention for consumers to buy it (Azhar, 2017; Patria, 2019). The benefits of social media as a marketing tool are very large so that businesses will lose opportunities if they do not use social media in marketing (Setiawati, 2015). This affects the allocation of advertising spending by companies. AC Nielsen Indonesia data shows that although advertising spending on television still dominates at $83 \%$, the trend is declining with a growth rate of only $6 \%$, while in the previous year it reached 13\% (Lubis, 2019). The opposite is shown in advertising spending on social media, which is valued at US\$ 446 million and is predicted to grow by $5.9 \%$ annually (Statista, 2020).

One of the social media that is often used for promotion is Instagram whose use as a promotional media has surpassed Facebook. with a global user base of 1.08 billion people in early July 2020 (Kemp, 2020). Of these users, the millennial generation is most affected by Instagram in their buying behavior. Loeb (2020) states that $72 \%$ of millennials use Instagram to get various information, it is including product information, 57\% follow fashion product trends through the media, and is predicted to spend up to US\$ 1.4 trillion in 2020. Therefore, it is important to understand the influence of social media on the buying behavior of millennials.

Shan et al. (2019) revealed a trend of using SMI services to increase sales and strengthen the brand's position in the minds of

Copyright: (c) 2021 the Author(s). This article is an open access article distributed under the terms and conditions of the Creative Commons Attribution (CC-BY) 4.0 license (https://creativecommons.org/licenses/by/4.0/). Published by Al-Kindi Centre for Research and Development, London, United Kingdom. 
consumers. Many academic studies have confirmed the influence of celebrities in increasing the effectiveness of advertising (Zhou et al., 2019). However, nowadays many companies are turning to social media influencers or micro-celebrities (hereinafter shortened to SMI), such as vloggers and 'instafamous' personality celebrities, to increase their brand value (Marwick, 2015). This is because social media such as Instagram are able to build and manage relationships between users and allow users to create usercreated marketing content that can be utilized by companies as brand owners. This phenomenon encourages the birth of SMI which also acts as a content creator. These SMls take advantage of their relationship with their followers so that their followers continue to follow the content they create continuously and follow what SMI is doing. For this reason, SMI must build a strong enough network with its followers by always actively posting interesting content and building a positive image in order to have a positive effect on the brand it promotes (Boerman et al., 2017; Taillon et al., 2020).

The trend of using SMI for promotion shows the importance of understanding how these influencers can influence consumers' purchase intentions. While the effectiveness of celebrities on the effectiveness of marketing in traditional media has been widely carried out (Bergkvist et al., 2016; Zhou et al., 2019), the role of SMI on consumer behavior is relatively new according to Lim et al. (2017). Previous research on SMI discussed more on the influence of personal characteristics of SMI on consumers' purchase intentions. Personal characteristics consist of trustworthiness, expertise, and attractiveness.

Gupta et al. (2015) stated that a trustworthy SMI is able to represent a good SMI image. The integrity of SMI who advertises a brand will create a sense of security for consumers, where they assume that the product benefits derived from using the brand will be the same as SMI who advertises it (Lassoued \& Hobbs, 2015). Therefore, success depends on the promotion of a brand image that is trustworthy SMI (believable), honest, and reliable (Ahmad et al., 2019; Wang \& Scheinbaum, 2018). Ahmad et al. (2019), Örs and Alawadhi (2020), and Zhou et al. (2019) state that if consumers think that SMI promoting a brand is trustworthy, then they will have a positive view of the promoted brand and ultimately increase their interest in buying the brand.

The credibility of an SMI can also be seen from its expertise based on the level of understanding, skills, and knowledge possessed of a product/brand (Ki et al., 2020; Wang \& Scheinbaum, 2017). The expertise of SMI can directly affect the level of consumer confidence in the brand it promotes so that it has a positive effect on brand attitudes and consumer buying interest. When consumers feel that an SMI has expertise in the brand, they tend to be more likely to trust the advertisements delivered by the SMI (Mansour \& Diab, 2016). Ulkhaq et al. (2016) found that SMI expertise has a greater impact on consumer purchase intentions than attractiveness and trustworthiness. An SMI who has knowledge and expertise on the product he recommends will be more effective in persuading consumers to buy the brand through his positive attitude towards the brand (Aw \& Labrecque, 2020). Meanwhile, Tanjung and Hudrasyah (2019) and Arora et al. (2019) stated that SMl's expertise significantly influences consumer attitudes towards the brands promoted by SMI and their buying interest.

Wang and Scheinbaum (2017) state that the attractiveness of an SMI can build intimacy between the SMI and its followers that it will have a positive influence on attitudes and buying interest in certain brands. According to Ha and Lam (2017), physical attractiveness, which is manifested through a person's weight, height, and facial beauty, is the first expression felt by others. Therefore, brand holders choose SMls who have a good personality, physical appearance, and charisma to advertise their brands because they are considered able to attract consumers' buying interest (Jacobson et al., 2020; Ki \& Kim, 2019; Lou \& Yuan, 2019). According to Agam (2017), it is very rare to find SMls that do not have the attractiveness of choosing a company to introduce a brand to consumers. This indicates that the attractiveness of SMI increases the effectiveness of advertising. Shan et al. (2019) revealed a trend of using SMI services to increase sales and strengthen the brand's position in the minds of consumers.

While research on the personal characteristics of SMIs has been widely conducted, this is not the case with studies that relate it to the suitability of SMIs with brands (Lim et al., 2017) and congruence between SMIs and their followers (Shan et al., 2019; Taillon et al., 2020). De Veirman et al. (2017) emphasize the importance of compatibility between brands and influencers so that the promotion of a brand has a positive impact. The effect of celebrity and brand congruence on traditional promotional media has often been discussed (Amos et al., 2008; Knoll \& Matthes, 2017), but the impact may be different for SMI, indicating the need for further testing. Brand holders must ensure the conformity of their brand image with SMI in order to have the maximum impact on their brand sales (Lim et al., 2017). Influencer-brand congruence is defined as the degree of match between accessible endorser associations and brand-related attributes (Kirmani \& Shiv, 1998). Several studies have found that influencer-brand congruence affects attitudes towards advertising and brands. Xu and Pratt (2018) found that if SMI's self-image matches the brand it promotes, then the brand will be considered good by consumers and increase their trust in the brand. Aw and Labrecque (2020) revealed that consumers will trust advertisements that use SMI which is able to transfer meaning from the product or brand it promotes. As a result, it will affect his attitude and buying interest towards the brand. Pereira (2018), Nugraha et al. (2018), and Zhou et al., (2019), expressed the same thing.

SMI is often considered to represent a certain reference group so that it will affect the buying interest of its followers. Shan et al. (2019) state every individual has a tendency to imitate the attitudes and behaviors of their idolized SMI. He will use SMI's advertised brands and products as a means to express and increase his confidence. Gavilanes et al. (2018) state that the self-image of an SMI (personal brand) can further influence the behavior of its followers if there are similarities in interests, attitudes, and behavior between influencers and followers. These similarities make the individual feel more emotionally connected to the SMI (Ki et al., 
2020). Therefore, the suitability of self-image between SMI and its followers will have an impact on consumer buying interest (Xu \& Pratt, 2018). Lim et al. (2017) and Shan et al. (2019) argues that the relationship between consumers and endorsers is important for the formation of brand image because the results of the research found that the congruence between the consumer's ideal self-image and SMI significantly affects consumers' attitudes towards the SMI and increases purchase intention. However, Taillon et al. (2020) found an insignificant effect.

The lack of research involving the suitability of SMI's image with brands and followers indicates that this needs to be tested further (Shan et al., 2019; Taillon et al., 2020). Based on this explanation, this study aims to analyze the effect of SMI characteristics (trustworthiness, expertise, and attractiveness), influencer-brand congruence, and self-influencer congruence on purchase intention through attitudes towards brands in the millennial generation.

\section{Method}

This study chooses the fashion industry as the research context because there is a tendency among Instagram users to seek information about these products from social media (Loeb, 2020). The research was conducted in Indonesia where the fashion industry is on the rise and many local brands whose quality is not inferior to foreign brands and has succeeded in penetrating the international market (Guide, 2018). Statistical data from BPS shows that the creative economy sector contributes significantly to the national economy, which is around $7.38 \%$, of which $18.5 \%$ comes from the fashion industry (Farid, 2019), and has a value of IDR 116 trillion (Creative Economy Agency, 2020).

The target population of this study is the millennial generation who use social media Instagram. This generation is more modernminded, can make decisions independently, and is an active social media user (Fani, 2019; Loeb, 2020). BPS data shows that the millennial generation in Indonesia reaches $33.75 \%$ of the total population. Respondents were selected using the technique of purposive sampling, where they should be followers of SMI fashion brands on Instagram as well as actively participating in the post/thread of the SMI last for at least 3 months.

Data was collected by distributing online questionnaires using google Forms. The survey link is distributed via Whatsapp and direct message on Instagram. All indicators measuring SMI characteristics were adopted from Ha \& Lam (2017) which consist of 5 indicators for trustworthiness, 7 indicators for expertise, and 5 indicators for attractiveness. Five indicators measuring influencerbrand congruence were also adopted from $\mathrm{Ha}$ and Lam (2017). Meanwhile, self-influencer congruence is measured through 5 indicators adopted from Hoffner and Buchanan (2005), McCroskey et al. (2004), and Taillon et al. (2020). Attitude toward the brand is measured by 5 indicators adopted from Kim and Kim (2020) and Kwon and Lennon (2009). The purchase intention variable is measured through 6 indicators adopted from Ha and Lam, (2017) and Shan et al. (2020). All of these indicators were measured using a 5-point Likert scale. The data collected were analyzed using PLS-SEM in order to be able to test the effect of the interdependent variables simultaneously. This analytical technique was chosen to maximize the predictive ability of this research model (Hair et al., 2018).

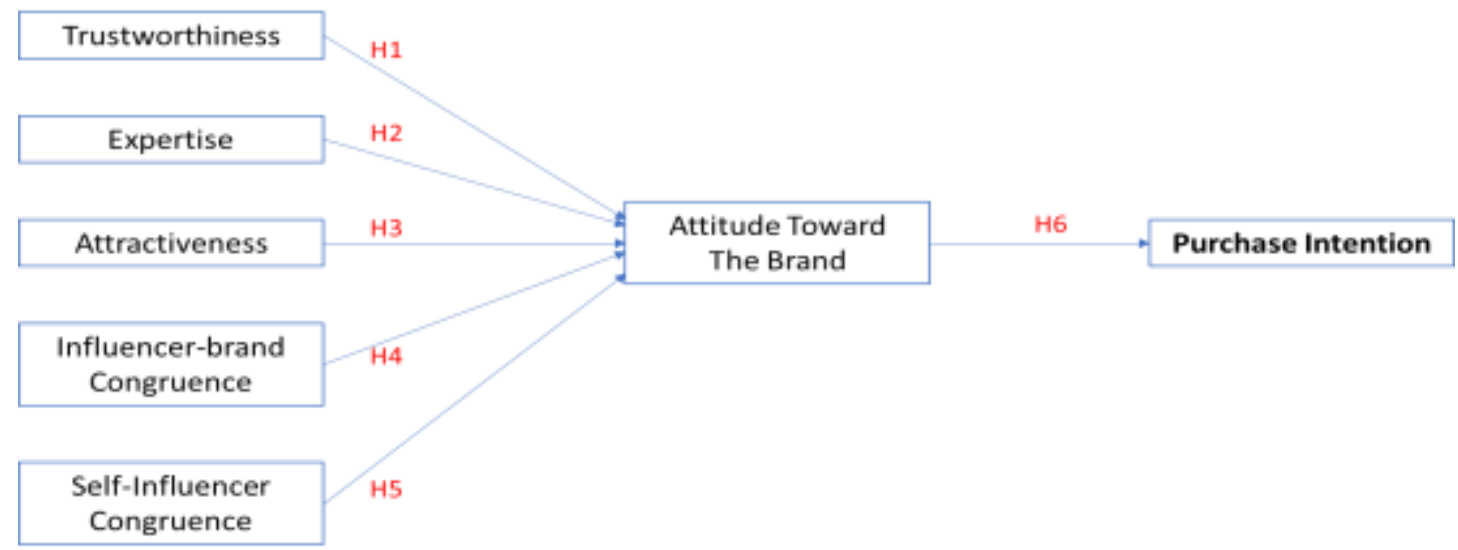

Figure 1. Research Model

\section{Results and Discussion}

\subsection{Results}

The number of samples that were collected was 250 respondents with details as shown in Table 1. The proportion of respondents by gender was almost equal, with slightly more female respondents than males. The majority of respondents are already working, accessing Instagram between 1 to 6 hours per day. When viewed from the frequency of respondents to follow posts/threads from SMI, $31 \%$ of respondents often pay attention to it and $18 \%$ always follow it. 
Table 1. Profile of Respondents $(n=250)$

\begin{tabular}{|c|c|c|}
\hline & Frequency & Percentage \\
\hline \multicolumn{3}{|l|}{ Gender: } \\
\hline Man & 110 & 44.0 \\
\hline Woman & 140 & 56.0 \\
\hline \multicolumn{3}{|l|}{ Age: } \\
\hline $20-25$ years & 125 & 50.0 \\
\hline $26-30$ years & 85 & 34.0 \\
\hline $31-35$ years & 28 & 11.2 \\
\hline $36-40$ years & 12 & 4.8 \\
\hline \multicolumn{3}{|l|}{ Work: } \\
\hline Student & 40 & 16.0 \\
\hline Private employees & 118 & 47.2 \\
\hline Government employees & 18 & 7.2 \\
\hline Businessman & 38 & 15.2 \\
\hline Other & 36 & 14.4 \\
\hline \multicolumn{3}{|l|}{ Use of Instagram Duration per day: } \\
\hline Less than 1 hour & 39 & 15.6 \\
\hline $1-3$ hours & 120 & 48.0 \\
\hline $4-6$ hours & 64 & 25.6 \\
\hline More than 6 hours & 27 & 10.8 \\
\hline \multicolumn{3}{|c|}{ Frequency of post/thread observations: } \\
\hline Every time there is a new post & 45 & 18.0 \\
\hline Often & 77 & 30.8 \\
\hline Sometimes & 99 & 39.6 \\
\hline Seldom & 29 & 11.6 \\
\hline
\end{tabular}

In the convergent validity test, it was found that the IBC4 indicator measuring influencer-brand congruence did not meet the criteria (factor loading $=0.266$ ), so it was excluded from the analysis. Table 2 shows the testing of convergent validity and construct reliability after removing invalid indicators. It appears that each construct has an AVE value between 0.665 and 0.805 , and a factor loading value between 0.754 and 0.922 , so it can be concluded that these indicators truly reflect the construct being measured. While the discriminant validity test with Fornell-Larcker (Table 3) shows the AVE square value is greater than the correlation value between constructs. The composite reliability value of all constructs is greater than 0.70 which indicates that all constructs are reliable.

Table 2. Mean, Standard Deviation, Loadings, AVE, Composite Reliability

\begin{tabular}{|c|c|c|c|c|c|}
\hline \multirow{2}{*}{ Construct } & \multirow{2}{*}{ Mean } & \multirow{2}{*}{ Std. Dev. } & \multicolumn{2}{|c|}{ Convergent Validity } & \multirow{2}{*}{$\begin{array}{l}\text { Composite } \\
\text { Reliability }\end{array}$} \\
\hline & & & Loadings & AVE & \\
\hline Trustworthiness & & & & \multirow[t]{5}{*}{0.790} & \multirow[t]{5}{*}{0.950} \\
\hline T1 & 3.86 & 0.91 & 0.884 & & \\
\hline $\mathrm{T} 2$ & 3.91 & 0.91 & 0.871 & & \\
\hline T3 & 3.92 & 0.88 & 0.896 & & \\
\hline T4 & 3.78 & 1.02 & 0.871 & & \\
\hline
\end{tabular}




\begin{tabular}{|c|c|c|c|c|c|}
\hline T5 & 3.92 & 0.89 & 0.922 & & \\
\hline Expertise & & & & 0.695 & 0.919 \\
\hline E1 & 3.94 & 0.92 & 0.789 & & \\
\hline E2 & 3.91 & 0.93 & 0.881 & & \\
\hline E3 & 3.82 & 0.88 & 0.848 & & \\
\hline E4 & 4.14 & 0.78 & 0.798 & & \\
\hline E5 & 4.00 & 0.81 & 0.848 & & \\
\hline Attractiveness & & & & 0.711 & 0.945 \\
\hline A1 & 4.26 & 0.78 & 0.840 & & \\
\hline $\mathrm{A} 2$ & 4.09 & 0.86 & 0.864 & & \\
\hline A3 & 4.25 & 0.71 & 0.834 & & \\
\hline A4 & 4.13 & 0.79 & 0.843 & & \\
\hline A5 & 4.22 & 0.74 & 0.864 & & \\
\hline A6 & 3.94 & 0.90 & 0.776 & & \\
\hline A7 & 4.12 & 0.77 & 0.878 & & \\
\hline Influencer-brand congruence & & & & 0.665 & 0.888 \\
\hline $\mathrm{IBC} 1$ & 4.28 & 0.74 & 0.754 & & \\
\hline IBC2 & 4.26 & 0.76 & 0.822 & & \\
\hline $\mathrm{IBC} 3$ & 4.27 & 0.71 & 0.867 & & \\
\hline IBC5 & 4.18 & 0.78 & 0.815 & & \\
\hline Self-influencer congruence & & & & 0.805 & 0.954 \\
\hline SIC1 & 3.71 & 0.98 & 0.894 & & \\
\hline SIC2 & 3.75 & 0.96 & 0.900 & & \\
\hline $\mathrm{SIC} 3$ & 3.74 & 1.02 & 0.898 & & \\
\hline SIC4 & 3.67 & 1.00 & 0.905 & & \\
\hline SIC5 & 3.56 & 1.17 & 0.889 & & \\
\hline Attitude toward the brand & & & & 0.725 & 0.929 \\
\hline ATB1 & 4.08 & 0.77 & 0.842 & & \\
\hline ATB2 & 4.10 & 0.75 & 0.888 & & \\
\hline ATB3 & 4.20 & 0.76 & 0.797 & & \\
\hline ATB4 & 4.02 & 0.86 & 0.872 & & \\
\hline ATB5 & 3.96 & 0.96 & 0.855 & & \\
\hline Purchase Intention & & & & 0.746 & 0.946 \\
\hline $\mathrm{PI} 1$ & 3.90 & 0.98 & 0.850 & & \\
\hline $\mathrm{PI} 2$ & 3.76 & 0.99 & 0.874 & & \\
\hline $\mathrm{PI3}$ & 3.96 & 1.00 & 0.831 & & \\
\hline $\mathrm{PI} 4$ & 3.86 & 0.99 & 0.892 & & \\
\hline $\mathrm{PI} 5$ & 3.91 & 1.00 & 0.832 & & \\
\hline PI6 & 3.86 & 1.02 & 0.899 & & \\
\hline
\end{tabular}


Table 3. Discriminant Validity Analysis

\begin{tabular}{|c|l|l|l|l|l|l|l|}
\hline & ATB & A & E & IBC & PI & SIC & T \\
\hline ATB & 0.851 & & & & & & \\
\hline A & 0.741 & 0.843 & & & & & \\
\hline E & 0.801 & 0.805 & 0.834 & & & & \\
\hline IBC & 0.491 & 0.527 & 0.539 & 0.816 & & & \\
\hline PI & 0.776 & 0.658 & 0.689 & 0.489 & 0.863 & & \\
\hline SIC & 0.639 & 0.510 & 0.621 & 0.434 & 0.639 & 0.897 & \\
\hline T & 0.707 & 0.719 & 0.807 & 0.512 & 0.720 & 0.564 & 0.889 \\
\hline
\end{tabular}

Furthermore, it is continued by testing the hypothesis for the structural equation model by considering the $p$-values for each construct. For the value of R-square attitude toward the brand 0.702 and purchase intention 0.603 . Table 4 shows that all hypotheses are supported, except for $\mathrm{H} 1$ and $\mathrm{H} 4$. It appears that expertise $(\beta=0.395 ; p<0.000)$ has the strongest influence on purchase intention through attitudes towards brands in the millennial generation, followed by attractiveness $(\beta=0.249, p<$ $0.002)$ and self-influencer congruence $(\beta=0.215 ; p<0.000)$ which supports $\mathrm{H} 2, \mathrm{H} 3$, and $\mathrm{H} 5$. Then the attitude toward the brand $(\beta$ $=0.776 ; \mathrm{p}<0.000$ ) has an influence on purchase intention in the millennial generation, so $\mathrm{H} 6$ is supported. Contrary to expectations, this study found that trustworthiness $(\beta=0.082 ; p=0.293$ ) and influencer-brand congruence had no effect on customer's attitude toward the brand $(\beta=0.012 ; p=0.822)$, so $\mathrm{H} 1$ and $\mathrm{H} 4$ were not supported.

Table 4. Discriminant Validity Analysis

\begin{tabular}{llllll}
\hline Hypothesis & Path coefficients & Std. Error & T-value & P-value & Information \\
\hline H1: $T \rightarrow$ ATB & 0.082 & 0.078 & 1.052 & 0.293 & Not supported \\
H2: E $\rightarrow$ ATB & 0.395 & 0.096 & 4,098 & 0.000 & Supported \\
H3: A $\rightarrow$ ATB & 0.249 & 0.080 & 3,115 & 0.002 & Supported \\
H4: IBC $\rightarrow$ ATB & 0.012 & 0.052 & 0.225 & 0.822 & Not supported \\
H5: SIC $\rightarrow$ ATB & 0.215 & 0.055 & 3,926 & 0.000 & Supported \\
H6: ATB $\rightarrow$ PI & 0.776 & 0.044 & 17,587 & 0.000 & Supported
\end{tabular}

Description: T: trustworthiness, E: expertise, A: attractiveness, IBC: influencer-brand congruence, SIC: self-influencer congruence, ATB: attitude toward the brand, PI: purchase intention.

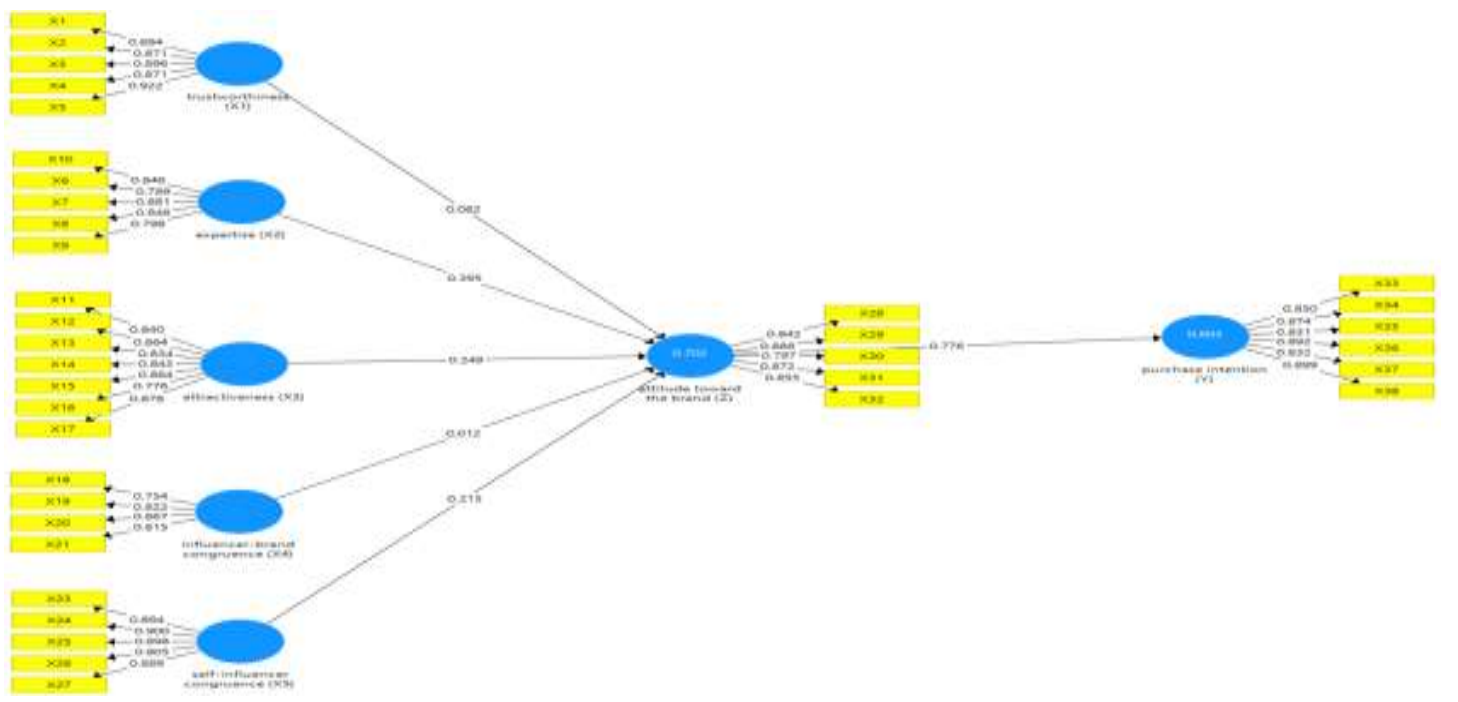

Figure 2. Results of Structural Model Testing 


\subsection{Discussion}

\subsubsection{Effect of Expertise on Attitude toward the Brand}

This study found that of the three personal characteristics of SMI, only SMI's expertise and attractiveness influenced consumer attitudes towards the brand. The findings regarding the positive influence of SMI expertise on brand attitudes are in accordance with the research of Ulkhaq et al. (2016) who found that SMI expertise had a greater impact on consumer purchase intentions than attractiveness and trustworthiness. Meanwhile, Tanjung and Hudrasyah (2019) stated that SMI's expertise significantly influences consumer attitudes towards the brands promoted by SMI and their buying interest. In this study, the knowledge and skills possessed by SMI for the brands it promotes are reflected through the information conveyed in its social media so that it is able to make consumers like the brand. An SMI who has knowledge and expertise on the product he recommends will be more effective in persuading consumers to buy the brand through his positive attitude towards the brand (Aw \& Labrecque, 2020).

\subsubsection{Influence of Attractiveness on Attitude toward the Brand}

In addition, this study found that SMI's physical attractiveness has an effect on consumers' attitudes towards brands. These results are in accordance with Wang and Scheinbaum (2017) who stated that the attractiveness of an SMI can build intimacy between the SMI and their followers. The attractiveness of SMI is able to attract followers so that it will have a positive influence on attitudes and buying interest in certain brands. The attractiveness is often measured by how attractive, classy, nice, stylish, and sexy SMI is (Örs \& Alawadhi, 2020). SMI with high attractiveness and positive image is considered to increase the image of the brand being promoted. Therefore, brand holders choose social media influencers who have a good personality, physical appearance, and charisma to advertise their brand because they are considered able to attract consumer buying interest (Jacobson et al., 2020; Ki \& Kim, 2019). According to Lou and Yuan (2019) and Taillon et al. (2020), SMI with high attractiveness is more effective and convincing than SMI that is not attractive, so it will foster buying interest. For the millennial generation involved in this research, SMI who looks professional, classy, and fashionable can influence consumers' judgments about the clothing brands they wear. They will like and find the brand attractive because it can improve the appearance of SMI who promote it.

\subsubsection{Effect of Trustworthiness on Attitude toward the Brand}

In contrast to Gupta et al. (2015), Ahmad et al. (2019), and Ha and Lam (2017) which state that a trustworthy SMI will increase consumers' positive attitudes towards the brand being promoted, this study finds that the effect of an SMI's trustworthiness on brand attitudes is not significant. The trust of a consumer is different from other consumers. This is in line with research conducted by Tessa (2020) which states that trustworthiness has no effect on attitudes. According to Dwyer and Oh (1987, in Gassenheimer \& Manolis, 2001), trust is the desire to achieve long-term goals. Trust has two dimensions, namely credibility, and benevolence. Credibility is based on belief in the expertise of partners to perform their duties effectively and reliably, while benevolence is a belief that partners will provide mutual benefits (Doney \& Canon, 1997). This explains that the initial creation of a relationship with a partner is based on trust. An SMI will get recognition from the public if they have expertise that makes them known and their credibility recognized so that this can make it easier for an SMI to carry out product or brand marketing communication activities (Schouten, Janssen, \& Verspaget, 2020). The concept of SMl's trustworthiness refers to its ability to be trusted, honest, and with integrity so that its followers believe that SMI provides convincing and correct information so that they believe in the brand promoted by SMI.

\subsubsection{Effect of Influencer-Brand Congruence on Attitude toward the Brand}

The trend of using SMI services to increase sales and strengthen the brand position in the minds of consumers is not only determined by the personal characteristics of SMI (Shan et al., 2019). An SMI will be more effective in promoting a brand if his/her self-image matches the advertised brand (Balasubramanian et al., 2006; Chen, 2016). Bergkvist et al. (2016) suggest that the influence of attitudes towards influencers and the influence of influencer's brand suitability on brand attitudes is fully mediated by attitudes towards SMI. However, the study found that the effect of influencer-brand congruence on the attitudes of the mark was not significant. This finding is in contrast to Amos et al. (2008) and Knoll and Matthes (2017) which state the significant positive effect of the celebrity/endorser-brand congruence variable on attitudes towards brands in traditional promotional media. It seems that in the context of the fashion brand promoted by SMI on social media, the influence-brand congruence element is less relevant to shaping attitudes towards the brand. Some of the millennials involved in this study feel that the fashion brands advertised by SMI are often not in accordance with the characteristics and self-image of SMI, which ultimately makes the impact not optimal on the sales of the brands it promotes. They tend to follow an SMI only based on the popularity of the SMI, while the SMI is sometimes not selective in choosing the fashion brands it promotes. As a result, an SMI can promote various brands at once, even though the brand is not in accordance with the self-image he builds. This makes the influencer-brand congruence unable to shape consumer attitudes towards the fashion brand promoted by SMI.

\subsubsection{Effect of Self-Influencer Congruence on Attitude toward the Brand}


This study found that self-influencer congruence has a significant influence on brand attitudes. This supports the argument in selfcongruence theory, which states that the suitability between an individual's image and an object will affect his behavior towards that object which is driven by his desire to maintain the consistency of his self-perception (Sirgy, 1991). This finding supports the research results of Shan et al. (2019). In this study, consumers will be more likely to like the brand promoted by SMI if they feel there are similarities between themselves and the SMI, especially in terms of how to express themselves and their mindset. The millennial generation is in a more mature age range where their self-concept has been formed. At this stage, they try to strengthen their existence and self-concept by choosing products that match the self-image they want to show. Even though their self-image has been formed, they still think of a self-image that is considered ideal. This ideal self-image is often projected through the SMI image they follow. Driven by his desire to feel comfortable while attending a certain SMI, he tends to choose an SMI that is in accordance with his ideal self-image. If this is fulfilled, then any product used by SMI is considered to represent the lifestyle that is considered ideal by the follower. Therefore, the more similar the self-image between the follower and SMI, the more positive the assumption is that the clothing brand promoted by SMI is suitable for him.

\subsubsection{Effect of Attitude toward the Brand on Purchase Intention}

Finally, this study found a significant positive effect of attitude toward the brand on consumer buying interest. The consumer's attitude towards the brand is determined by his experience of the brand and the public figures who promote the brand (Liu et al., 2007), and ultimately affect the purchase intention of a product. Brand attitudes tend to influence the choice of one brand over another. When customers have a more positive attitude towards a brand, they are more likely to intend to buy the product. Susilowati et al. (2020) found that consumer' attitudes towards SMI and brands positively affect the purchase intention of the millennial generation, but the influence of attitudes towards brands is much greater than attitudes towards celebrities in generating purchase intentions. These findings support the research of Ha and Lam (2017), Nugraha et al. (2018), and Tanjung and Hudrasyah (2019) who found that purchase intention was strongly influenced by consumers' positive attitudes towards brands promoted by SMI. If consumers think that a brand is attractive and like the brand, then they will be more motivated to look for the brand and buy it. This supports the theory of consistency between attitudes, intentions, and behavior.

\section{Conclusion}

This study develops a research model on the effect of SMI characteristics on purchasing behavior by including influencer-brand congruence and self-influencer congruence variables. The results show that buying interest in clothing brands is strongly influenced by consumer attitudes towards the brand. Meanwhile, this attitude is shaped by consumer perceptions of SMI's expertise, attractiveness, and influencer-brand congruence.

Fashion brand companies need to understand the influence of social media on the buying behavior of the millennial generation. In deciding which SMI will promote its brand, the company needs to ensure that the SMI has in-depth knowledge of the brand it promotes because it will affect the content it creates to promote the brand. For fashion products, physical appearance plays an important role in shaping consumer attitudes towards the brand. Therefore, companies should choose SMI that has a high allure. The attraction is seen from the style of the dress where the millennial generation likes SMI who looks professional, classy, and fashionable.

In addition, companies must pay attention that the selected SMI is in accordance with the target market of the brand being promoted. Given the potential of SMI to promote a brand, SMI must be able to take advantage of its relationship with its followers. He also has to really study the brand of the product being promoted in order to be able to produce interesting and quality content that makes his followers continue to follow the content he creates and follow SMI's consumption behavior. SMI must build a strong enough network with its followers by always actively uploading content and building a positive image in order to have a positive effect in the form of increasing purchase intention for the brand it promotes.

This research only focuses on the millennial generation so it is recommended for further research to reach consumers from other generations to validate the theory tested in this study. This study also only involved respondents in Indonesia, where consumer behavior in each country may vary due to cultural influences and their level of maturity in using social media. Therefore, further research should be carried out in other countries or conduct comparative studies between cultures. Further research can also add other variables such as customer-brand engagement and brand equity. The uniqueness of marketing through social media is its interactive nature which allows brands to build personal relationships with consumers and will affect their brand equity. 


\section{References}

[1] Agam, DNLA (2017). Celebrity endorser physical attractiveness effect on consumers' attitude toward online advertisement. Australian Journal of Accounting, Economics, and Finance, 3 (1), 25-29.

[2] Ahmad, AH, Idris, I., Mason, C., \& Chow, SK (2019). The impact of young celebrity endorsements in social media advertisements and brand image towards the purchase intention of young consumers. International Journal of Financial Research, 10 (5), 54 65. https://doi.org/https://doi.org/10.5430/ijfr.v10n5p54

[3] Amos, C., Holmes, G., \& Strutton, D. (2008). Exploring the relationship between celebrity endorser effects and advertising effectiveness: A quantitative synthesis of effect size. International Journal of Advertising, 27 (2), 209-234. https://doi.org/10.1080/02650487.2008.11073052

[4] Arora, A., Bansal, S., Kandpal, C., Aswani, R., \& Dwivedi, Y. (2019). Measuring social media influencer index-insights from Facebook, Twitter, and Instagram. Journal of Retailing and Consumer Services, 49, 86-101. https://doi.org/10.1016/j.jretconser.2019.03.012.

[5] Aw, ECX, \& Labrecque, LI (2020). Celebrity endorsements in social media contexts: understanding the role of parasocial interactions and the need to belong. Journal of Consumer Marketing, 37 (7), 895-908. https://doi.org/10.1108/JCM-10-2019-3474

[6] Azhar. (2017). Changing business strategies to stay afloat in the digital era.

[7] Creative Economy Agency. (2020). Creative economy performance report 2019. Jakarta: Ministry of Tourism and Creative Economy of the Republic of Indonesia. Journal of Materials Processing Technology, 1(1), 1-8.

[8] Bergkvist, L., Hjalmarson, H., \& Mägi, AW (2016). A new model of how celebrity endorsements work: attitude toward the endorsement as a mediator of celebrity source and endorsement effects. International Journal of Advertising, 35 (2), 171184. https://doi.org/10.1080/02650487.2015.1024384

[9] Gupta, R., Kishore, N., \& Verma, D. (2015). Celebrity endorsements in advertising: impact on consumers' perception, attitude and purchase intention. Australian Journal of Business and Management Research New South Wales Research Center Australia (NSWRCA), 5(3), 1-15.

[10] Ha, NM, \& Lam, NH (2016). The effects of celebrity endorsement on customers' attitudes toward brand and purchase intention. International Journal of Economics and Finance, 9 (1), 64. https://doi.org/10.5539/ijef.v9n1p64

[11] Hoffner, C., \& Buchanan, M. (2005). Young adults' wishful identification with television characters: The role of perceived similarity and character attributes. Media Psychology, 7 (4), 325-351. https://doi.org/10.1207/S1532785XMEP0704_2

[12] Isaac, A. (2008). The effect of using celebrities in advertising on consumer buying interest. Journal of Business Strategy, 12 (2), $21-22$.

[13] Jacobson, J., Gruzd, A., \& Andez-García, H. (2020). Social media marketing: Who is watching the watchers? Journal of Retailing Consumer Service, 53, 1-12. https://doi.org/https://doi.org/ 10.1016/j.jretconser.2019.03.001.

[14] Kemp, S. (2020). Digital use around the world in July 2020.

[15] Khamis, S., Ang, L., \& Welling, R. (2018). Self-branding, 'micro-celebrity and the rise of Social Media Influencers. International Journal of Advertising, 8(2), 191-208. https://doi.org/10.1080/19392397.2016.1218292

[16] Ki, CW 'Chloe,' Cuevas, LM, Chong, SM, \& Lim, H. (2020). Influencer marketing: Social media influencers as human brands attach to followers and yield positive marketing results by fulfilling needs. Journal of Retailing and Consumer Services, 55(January), 102133. https://doi.org/10.1016/j.jretconser.2020.102133

[17] Kim, DY, \& Kim, HY (2020). Influencer advertising on social media: The multiple inference model on influencer-product congruence and sponsorship disclosure. Journal of Business Research, 130, 405-415. https://doi.org/10.1016/j.jbusres.2020.02.020

[18] Kim, M., \& Song, D. (2017). When brand-related UGC induces effectiveness on social media: The role of content sponsorship and content type. International Journal of Advertising, 37 (1), 105-124. https://doi.org/10.1080/02650487.2017.1349031

[19] Kirmani, A., \& Shiv, B. (1998). Effects of source congruity on brand attitudes and beliefs: The moderating role of issue-relevant elaboration. Journal of Consumer Psychology, 7 (1), 25-47. https://doi.org/10.1207/s15327663jcp0701_02

[20] Knoll, J., \& Mathes, J. (2017). The effectiveness of celebrity endorsements: a meta-analysis. Journal of the Academy of Marketing Science, 45 (1), 55-75. https://doi.org/10.1007/s11747-016-0503-8

[21] Lassoued, R., \& Hobbs, JE (2015). Consumer confidence in credence attributes: The role of brand trust. Food Policy, 52, 99107. https://doi.org/10.1016/j.foodpol.2014.12.003

[22] Lim, XJ, Mohd-Radzol, AR, Cheah, J.-H., \& Wong, MW (2017). The impact of social media influencers on purchase intention and the mediation effect of customer attitude. Asian Journal of Business Research, 7 (2), 18-36. https://doi.org/10.14707/ajbr.170035

[23] Loeb, W. (2020). Social media plays a big role in how millennials shop, but so do stores.

[24] Lou, C., \& Yuan, S. (2019). Influencer marketing: How to message value and credibility affect consumer trust of branded content on social media. Journal of Interactive Advertising, 19 (1), 58-73. https://doi.org/10.1080/15252019.2018.1533501

[25] Lubis, M. (2019). Digital ad spending accounts for $6 \%$ of total ad spending.

[26] Nugraha, R., Kusumawardani, KA, \& Octavianie, V. (2018). The influence of celebrity endorsement in Instagram towards customer behavior and purchase intention in healthy food diet business. Firm Journal of Management Studies, 3 (2), 124. https://doi.org/10.33021/firm.v3i2.476

[27] Örs, M., \& Alawadhi, R. (2020). Effect of celebrity endorsement on consumers' purchase intention in the mediation effect of brand image. Journal of Business Research - Turk, 12 (1), 454-468. https://doi.org/10.20491/isarder.2020.855

[28] Patria, R. (2020). 2019 social media marketing trends.

[29] Pereira, ARMTC (2018). The impact of sources of credibility on purchase intentions of different beauty products: mediator effect of perceived quality. Universidade Catolica Portuguesa.

[30] Setiawati, M. (2015). The influence of social media on consumer buying interest: A case study of management students at Pasir Pengaraian University. Student Journal of Management Study Program, Faculty of Economics, 2 (2), 1-14.

[31] Shan, Y., Chen, K.-J., \& Lin, J.-S. (2019). When social media influencers endorse brands: the effects of self-influencer congruence, parasocial identification, and perceived endorser motive. International Journal of Advertising, 39 (5), 590-

610. https://doi.org/https://doi.org/10.1080/02650487.2019.1678322

[32] statistics. (2020). Social media advertising: Indonesia. 
[33] Susilowati, FD, Futuwwah, Al, Susilowati, FD, \& Futuwwah, Al (2020). The effect of endorser type and endorser-brand compatibility on attitudes towards endorsers, brands, advertisements, and purchase intentions of Muslim hijab fashion on Instagram. Journal of Management and Business Research, 5 (3), 419-436.

[34] Taillon, BJ, Mueller, SM, Kowalczyk, CM, \& Jones, DN (2020). Understanding the relationships between social media influencers and their followers: the moderating role of closeness. Journal of Product and Brand Management, 29 (6), 767-782. https://doi.org/10.1108/JPBM-032019-2292

[35] Tanjung, S., \& Hudrasyah, H. (2019). The impact of celebrity and non-celebrity endorser credibility in the advertisement on attitude towards advertisement, attitude towards the brand, and purchase intention. International Conference on Ethics of Business, Economics, and Social Science, 231-245

[36] Ulkhaq, MM, Nurdianti, AR, Kartika, M., \& Astharina, V. (2016). A confirmatory factor analysis of the source model for celebrity endorsement. Journal of Management, Marketing, and Logistics, 3 (1), 28-37. https://doi.org/10.17261/Pressacademia.2016116527

[37] Wang, S., \& Scheinbaum, AC (2017). Trustworthiness trumps attractiveness and expertise: enhancing brand credibility through celebrity endorsement. Journal of Advertising Research, 58 (1), 1-39. https://doi.org/10.2501/JAR-2017-042

[38] We Are Social. (2020). Global digital overview.

[39] Xu, RX, \& Pratt, S. (2018). Social media influencers as endorsers to promote travel destinations: an application of self congruence theory to the Chinese Generation Y. Journal of Travel \& Tourism Marketing, 35 (7), 1-15. https://doi.org/10.1080/10548408.2018.1468851

[40] Zhou, M., Rajamohan, S., Hedrick, V., Patiño, SRG, Abidi, F., Polys, N., \& Kraak, V. (2019). Mapping the celebrity endorsement of branded food and beverage products and marketing campaigns in the United States, 1990-2017. International Journal of Environmental Research and Public Health, 16 (19), 3743. https://doi.org/10.3390/ijerph16193743 